\title{
IAMJ
}

INTERNATIONAL AYURVEDIC MEDICAL JOURNAL

\section{ROLE OF UTTARA VASTI IN REGULATION OF HYPOTHALAMO-PITUITARY - OVARIAN-AXIS}

\author{
K. Sribala ${ }^{1}$, Kola Vijayakumari ${ }^{2}$ \\ ${ }^{1}$ Final Year, PG Scholar, Dept of Prasutitantra \& Sreeroga, DR.N.R.S. GOVT Ayurvedic College, \\ Vijayawada, Andhra Pradesh, India \\ ${ }^{2}$ Guide \& H.O.D (MD Ayu), DR.N.R.S. GOVT Ayurvedic College, DEPT of Prasutitantra \& Streeroga, \\ Vijayawada, Andhra Pradesh, India
}

Corresponding Author: sribala.ravikanth@gmail.com

\section{https://doi.org/10.46607/iamj12p6012021}

(Published Online: November 2021)

Open Access

(C) International Ayurvedic Medical Journal, India 2021

Article Received: 18/09/2021 - Peer Reviewed: 05/10/2021 - Accepted for Publication: 07/10/2021

\begin{abstract}
In Ayurveda, the branch Prasutitantra \& Streeroga Vijnana (Obstetrics \& Gynaecology) significantly deals with extended varieties of gynaecological disorders, the best antenatal, intranatal and postnatal care ensuring a healthy mother and child.to ensure the aim and objective, the most efficient procedure Uttaravasti (intrauterine medication) is considered a boon for the branch.it is an important therapeutic procedure pertaining to Genitourinary applications in both males and females in Prasuti Tantra \& Streeroga, Uttaravasti involves administration of specific medicated oil, Ghritam (ghee) or Kashaya (decoction)into the genital tract viz intravaginal or intrauterine. Useful in infertility, spontaneous abortions, fibroids, tubal blockages, DUB, dysmenorrhea etc., which denotes the action of Uttaravasti chiefly intended to regulate the most functional aspect of the female the hypothalamo-pituitary-ovarian-axis. intravaginal application of Uttaravasti helps in removing infections, facilitate absorption of drug applied. Uttaravasti given with lower amounts of medicine removes the stenosis disorders, thereby relieving dysmenorrhea. intrauterine application of uttaravasti helps in rejuvenation of endometrium, correction of hyperplasia, removal of lumen blockages thereby restoring the normal functioning of the H-P-O axis by absorption. Thus Uttaravasti, the procedure which by outlook understood is far less to its functional efficacy which is clinically experienced on patients.
\end{abstract}

Keywords: Prasutitantra, Streeroga, uttaravasti, hypothalamus, pituitary gland, endometrium H-P-O axis. 


\section{INTRODUCTION}

Ayurveda, the science of life throws light on healthy living rather than living for longer durations with ailments because the ultimate aim of life i.e. the emancipation is attained only through the chronological attainment of righteousness, wealth obtained through a righteous job, desire for healthy life and progeny and finally the emancipation through the preceding deeds here in the science of Prasuti tantra and Stree roga emphasising on assurance of health for two i.e. mother and child postulates certain local procedures for the attainment of Shodana (elimination)locally and Brihmana (nourishment)of local tissues for proper functioning. The procedure Uttaravasti, though not placed as Panchakarma but as Uttara karma (a procedure that is done after). The medicine administered may be in the form of Kashaya or Sneha, but administration time is only after one technical Shodana vasti (enema for cleansing) course on the patient. In Ayurveda, the place of Vata dosha \& its function is mentioned as "Adah kaya" (lower half of the body). The lower half of the body and the root cause of all gynaecological disorders in vata dosha, therefore the Vatahara (mitigating vata dosha) management "uttaravasti" given locally is understood as highly efficacious.

\section{Concept of Uttaravasti:}

"Uttara Marga deeyamanatayaa Uttara Vasti sangna".

The Vasti given as Paschat Karma to the Shodana Vasti it is termed as Uttaravasti. Also, the mode of administration being "Gudasya Uttaramargavtat" (administered through the vagina) i.e., Given through the opposite orifice to Guda Marga (rectal route) say Mutrashaya gata (urethral route) or Garbhashaya gata

(Uterine administration). The one more term being significant acc to chakrapani Datta commentary on Charaka Sidddhisthana is "Kimva Shrestha Guna Taya Uttaravasti". The efficacy of administration is best among all the procedures is named after its effect as "uttaravasti."
The Uttaravasti has been explained in 2 points of view i.e.

1. Mutrashaya Gata Vasti - through the urinary passage

2. Garbhashaya Gata Vasti - vaginal route

Herein, the garbhashaya gata vasti in regulating H-P$\mathrm{O}-$ axis is deal with.

\section{Garbhashaya Gata Vasti:}

In this type of Uttara vasti, the vasti dravya is administration into the uterus via a vaginal orifice. This helps in expelling out of Sthanika dosha (vitiated), also corrects the whole urogenital system through the carried out active principle into the H-P-O axis through the mucosal absorption of the drug.

\section{Uttaravasti - classification:}

The procedure is classified based on many parameters.

i. Based on drug administered

a. Snaihika Uttaravasti - Sneha Dravya is used as medicine for application and there is no additional avapa required for it.

b. Niruha Uttaravasti - Kashaya Dravya Along With Sneha Nirvapa is used for the administration of Uttaravasti.

ii. Based on route of administration

a. Mutrashaya Gata-urethral route

b. Yonigata - through vaginal route

c. Garbhashaya Gata - Intra uterine via a cervical canal

\section{Indications of Uttaravasti:}

Uttaravasti, being a Sthanika Chikitsa has got its limitations for administration, the indication for administering Uttaravasti are enumerated as follows

- Sukra dushti

- Shonita or Artava dushti (menstrual abnormalities of female)

- As a Chikitsa (management) for Yonivyapad-like tubal blockages

- Vandhya chikitsa (to regulate hormonal axis)

- In retained placenta (Apara samsthithi)

Contraindications:

Garbhashaya Gata Uttara Vasti in virgin women. In Rajah kala (menstrual phase) of a woman 
Time of administration: The procedure Uttaravasti is said to be administered in Ritu kala (ovulatory phase) according to classic texts.

To be administered only after 2 or 3 Asthapana vasti as the Shodhana allows more absorption of the later administered medicine and in rtukala, the dravya is readily received by the yonimarga due to its permeable absorption activity during that particular period.

Probable mode of action: (When administered intravaginally)

The Uttaravasti Dravya could act both systemic and local when administered intravaginally. This is through the network of blood vessels existing in the pelvic region say branches of int. Iliac artery, uterine artery and middle rectal and internal pudendal arteries abundantly supply the vaginal walls. Therefore, the vascular effect of vaginal tissues causes the uterine pass effect i.e., transfer of vaginal administered drug into the uterus. It is clear through contemporary evidence-based sciences that the higher concentration of progesterone in the uterus is responsible for better absorption of drugs administered intravaginally. Thus, it is to be understood that the vaginal canal because of its histopathological support, transports the drug across the vaginal membrane.

Transcellular (across epithelial cells) - through diffusion

Para cellular (between epithelial cells - mediated via junctions)

Vesicular transport (through receptors)

Therefore, drug absorption in which it is administered could be absorbed in the following manner

- Dissolution in vaginal layers \& membrane penetration

- The dissolution into vaginal fluids

Factors that affect the above mechanism could be

a. Physiochemical drug properties

b. Low molecular weight lipophilic form or hydrophilic form

c. Contact time - prolonged contact time increases absorption.
MODE OF ACTION IN GARBHASHAYA GATA UTTARA VASTI: Theoretically, as per the text, the procedure Uttaravasti administered is intended to act on Garbhashaya (reproductive system) directly.

The Virya (potency)of the drug administered reach into the Garbhashaya(uterus) through the following mechanisms.

- Direct passive diffusion through local tissues.

- Through cervical lumen

- Through venous or lymphatic circulation.

- Vascular exchange, diffusion between veins \& arteries.

The arterial supply of the uterus is the uterine artery (branch of int. iliac artery), ovarian arteries (branches of the aorta).

The venous drainage of the uterus is into the iliac veinthe drug administered into the uterus acts locally by FIRST PASS EFFECT.

Through perfusion, it is reported that the drug applied in vaginal tissue reaches and acts on the uterus within 5hours of application.

The size of particles below $90 \mathrm{~m}$ TC is studied to be reaching the uterus within a minute indicating a direct transport mechanism involving aspiration through the cervical canal.

The drug administered at the opening of the cervix travels towards the uterus by the osmolarity of the Sneha dravya given.

The Sneha dravya which remains inside may show systemic effect by being absorbed and --transported into inferior vena cava by vaginal, retro sigmoidal, vesicular, and uterine veins.

In recent time studies, it has been studied that any medicinal formulation placed intravaginally, the drug absorbed in outer $1 / 3^{\text {rd }}$ of the vagina passes uterus dramatically, influences first uterine pass effect and activating feedback mechanism till hypothalamus.

This process occurs via the following sequel.

Stimulating ovaries-----pituitary stimulation------hypothalamus activation and thereby indicates the nourishment and rebounding functionality in the order vice versa i.e. Hypothalamus----pituitary gland---gonads (ovaries)-----uterus (myometrium, endometrium)

Till pacemakers of the uterus. 


\section{DISCUSSION}

The fundamentals and basic principles of any science, on which it is primarily based would never be changed but could be practically demonstrated w.s.r to their principles, reliability, and utility in the present-day scenario. Say, the instruments, line of treatment can be modified (keeping the core principles intact).

In the present context, the action of Uttara vasti grossly depends on the drug used, method of installation, instrument used etc. Medicine is more likely to exhibit local effects at the target site.

The drug administered in the cervical canal influences cervical factors and feedback to the hypothalamus to rectify cervical factor abnormalities.

The capillaries absorb the medicine, Through and venules, the medicament absorbed by its permeability action and diffusion mechanism where the cell membrane of ovaries may have a diffusion of drug through its permeability.

With this absorption, there may be the promotion of folliculation of primordial follicles. The probable action would be absorption medicine -flowing into the circulation - reaches the hypothalamus and thereby pituitary gland-influences GnRH-may perform to stimulate the ovarian axis. With this, the unseen manifestation of ovulation, visualised as menstruation, is inferred for the proper functioning of the HPO axis in a proper physiological manner.

Intra vaginal uttaravasti helps in removing infection, where posterior fornix within pampiniform plexus a rich blood supply, and it may also act as a reservoir of the drug.

Uttaravasti given into cervix (ext. Os) with oil-based drug helps to remove cervical stenosis and to restore the function of the cervix in conception and also as management in dysmenorrhea (w.s.r to a drug applied).

If the drug administered is Brimhana in action, it stimulates the secretion of cervical mucus leading to an ascent of sperm physiologically into the uterine cavity. If the drug is administered as Uttara Vasti deep into the intrauterine level, with Ghritam based drugs helps in rejuvenation of endometrium, especially where apart from regular ovulation, poor endometrium causes infertility or scanty menstruation.

In the same manner, Uttaravasti with Lekhana Dravyas (lipolytic) in hyperplastic conditions of the endometrium is indicated.

Uttaravasti removes lumen blockages by directly acting on obstruction mechanically and restores the normal function of cilia by stimulating it.

As endometrial covering is continuous in the tubes too, it's scraping through Teekshna (penetrative) Lekhana action of drug locally, its regeneration also leads to normalisation of tubal functions.

The factor, length of the nozzle used for uttaravasti in females is 4 Angula from the tip of the nozzle (as mentioned in classics) i.e., $12 / 14 \mathrm{~cm}$ approximately $8 \mathrm{~cm}$ for uterine administration.

The maximum amount of drug that could be administered as mentioned in classics is one Prakuncha $(\sim 50 \mathrm{ml})$ if it is Sneha dravya, one Prasruta $(80 \mathrm{ml})$ for Kashaya.

The drug once administered is expected to stay inside the bladder for a considerable period, still before the micturition reflex comes into action. as far as the mode of administrations of Uttaravasti vaginal and intrauterine considered, the vaginal bioavailability varies according to the above-mentioned factors.

The observation being the permeability factor in a normal uterus and atrophied uteri is the same which substantiates that its action is on H-P-O Axis usually.

\section{CONCLUSION}

The procedure Uttaravasti, being a boon to the science of gynaecology shall not be confined to diseases like infertility.it is mentioned as a line of management for many gynaec disorders as per Ayurveda. Indeed, a better understanding of urothelial permeability could help to optimise the treatment. despite its higher efficacy, clinical research to explore the mode of action $u t$ taravasti is yet to be done to know the urothelial permeability. 


\section{REFERENCES}

1. Chakrapani, Commentator, Charaka, Drudhbala, Charaka Samhita- Sutra Sthana-Ayushkameeya adhyaya-1/41, Vaidya Yadavji Trikamji Acharya, editor. New Delhi: Chaukhambha publication; Reprint 2014; pg. 121

2. Chakrapani, Commentator, Charaka, Drudhbala, Charaka Samhita- Sutra Sthana-Ayushkameeya adhyaya-1/41, Vaidya Yadavji Trikamji Acharya, editor. New Delhi: Chaukhambha publication; Reprint 2014; pg. 128

3. Chakrapani, Commentator, Charaka, Drudhbala, Charaka Samhita- siddhi Sthana- Trimarmeeya siddhi9/, Vaidya Yadavji Trikamji Acharya, editor. New Delhi: Chaukhambha publication; Reprint 2014; pg. 741

4. Vagbhata, Ashtanga Sangraha, Sutrasthana - Doshadi vignaneeya 11/. Ravi Dutta Tripathi, editor. Delhi: Chaukhambha Sanskrit Pratishthan; pg. 389

5. Chakrapani, Commentator, Charaka, Drudhbala, Charaka Samhita-sutra Sthana-Ayushkameeya adhyaya-1/41 Vaidya Yadavji Trikamji Acharya, editor. New Delhi: Chaukhambha publication; Reprint 2014; pg. 110

6. Chakrapani, Commentator, Charaka, Drudhbala, Charaka Samhita-sutra Sthana-Trimarmiya Sidddhi adhyaya-9/50, Vaidya Yadavji Trikamji Acharya, editor. New Delhi: Chaukhambha publication; Reprint 2014; pg. 745

7. Vagbhata, Ashtanga Sangraha, Sutrasthana -Bastividhiadhyay,28/9. Ravi Dutta Tripathi, editor. Delhi: Chaukhambha Sanskrit Pratishthan; 504pg

8. Hemadri commentary, Vagbhata, Ashtanga Hridayam, Sutrasthana - Bastividhiadhyay, 19/70. Pandit Hari Sadashiva Shastri Paradakar, editor. Varanasi: Chaukhambha Sanskrit Samsthana; Reprint 2014,283 pg.

9. Sushruta. Susruta Samhita. Anuvasnotarbasti Chikitsa Adhyay37/125-126. Ambika Dutta Shastri, editor Varanasi: Chaukhambha Sanskrit Samsthana; 207pg

10. Charaka, Drudhbala, Charaka Samhita- Siddhi SthanaTrimarmiya adhyaya-9/63-64. Pandit Rajeshwaradatt Shastri, editor. Varanasi: Chaukhambha publication; Reprint 2015; 1065pg

11. Vagbhata, Ashtanga Sangraha, Sutrasthana -Basti Vidhi adhyaya,28/526. Ravi Dutta Tripathi, editor. Delhi: Chaukhambha Sanskrit Pratishthan;526 pg.
12. Susruta. Susruta Samhita. Anuvasnotarbasti Chikitsa Adhyay37/107, Ambika Dutta Shastri, editor Varanasi: Chaukhambha Sanskrit Samsthana; 205pg

13. Charaka, Drudhbala, Charaka Samhita- Siddhi SthanaTrimarmiya Siddhi adhyaya, 9/50-51, Pandit Rajeshwaradatt Shastri, editor. Varanasi: Chaukhambha publication; Reprint 2015; 1063 pg.

14. Arunadatta, Commentator. Vagbhata. Ashtanga Hridayam. Sutrasthana, Bastividhiadyay, 19/73, Pandit Hari Sadashiva Shastri Paradakar, editor. Varanasi: Chaukhambha publication; Reprint 2014; 283 pg.

15. Susruta. Susruta Samhita. Chikitsa Sthana, Anuvasnotarbasti Chikitsa Adhyay37/113, Ambika Dutta Shastri, editor Varanasi: Chaukhambha Sanskrit Samsthana; 206pg

16. Vagbhata. Ashtanga Hridayam. Sutrasthana, Bastividhiadyay,19/81-82, Vd. Yadunandan Upadhyay, editor. Varanasi: Chaukhambha Sanskrit Samsthana; $126 \mathrm{pg}$

17. Pulak Kanti Kar. Mechanism of Panchakarma and its Module of Investigation. Varanasi: Chaukhambha Sanskrit Pratishthan; 2013,95 pg.

18. Golomb, Avramoff, Hoffman. A New Route of Drug Administration: Intrauterine Delivery of Insulin and Calcitonin. Pharm Res. Jun1993; 10(6): 828-33pg.

\section{Source of Support: Nil \\ Conflict of Interest: None Declared}

How to cite this URL: K. Sribala \& Kola Vijayakumari: Role Of Uttara Vasti In Regulation Of Hypothalamo-Pituitary Ovarian-Axis. International Ayurvedic Medical Journal \{online\} 2021 \{cited November 2021\} Available from: http://www.iamj.in/posts/images/upload/3235_3239.pdf 